\title{
Anemia following zinc treatment for Wilson's disease: a case report and literature review
}

\author{
Sha Cai ${ }^{1}$, Jing-Yu Gong ${ }^{1}$, Jing Yang ${ }^{1}$ and Jian-She Wang ${ }^{1,2^{*}}$ (D)
}

\begin{abstract}
Background: Zinc therapy is considered an effective and safe treatment for Wilson's disease. Hypocupremia-related anemia is rarely reported after long-term zinc administration or combination therapy with copper-chelating agent.

Case presentation: We herein report a 12-year-old girl with pre-symptomatic Wilson's disease diagnosed 5 years ago who presented with severe anemia after high-dose oral zinc for 4 years and 4 months. Her hemoglobin was gradually restored to the normal range after the adjustment of zinc dose and diet therapy for 4 months. A review of the literature revealed eight patients with hypocupremia-associated anemia following zinc therapy for Wilson's disease, including 7 adults and 1 child. The only child patient was a 16-year-old boy, in whom the zinc therapy was succession to penicillamine administration.

Conclusions: This is the first report worldwide that a child developed severe anemia following high-dose single zinc administration for Wilson's disease. It highlights the importance of regular follow-up during zinc treatment and the involvement of specialists in the long-term management of Wilson's disease. We hope that this will alert pediatricians the issue of zinc over-treatment.
\end{abstract}

Keywords: Wilson's disease, Hepatolenticular degeneration, Zinc, Hypocupremia, Anemia

\section{Background}

Wilson's disease (WD), first reported by Kinnear Wilson in 1912 [1], is an autosomal recessive inherited disease. It is caused by dysfunction of the ATP7B gene [2] which affects the formation of ceruloplasmin and impairs copper secretion into bile, resulting in excessive copper deposition in the liver, brain and other tissues, and leads to a series of clinical manifestations including hepatic, neurological and psychiatric symptoms [3-6].

Zinc is believed to be a safe and effective first-line drug in treatment of WD. Gastrointestinal reactions and hepatic deterioration are relative common side effects of zinc therapy [7-9]. Hypocupremia-associated anemia after long-term copper depletion therapy in WD is rare. Only eight patients with anemia after a long period of zinc therapy for WD have been reported [10-17]. Here,

\footnotetext{
* Correspondence: jshwang@shmu.edu.cn

'Department of Pediatrics, Jinshan Hospital of Fudan University, 1508 Longhang Road, Jinshan District, Shanghai 201508, China

${ }^{2}$ Center for Pediatric Liver Diseases, Children's Hospital of Fudan University, Shanghai 201102, China
}

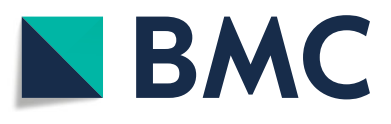

(c) The Author(s). 2019 Open Access This article is distributed under the terms of the Creative Commons Attribution 4.0 International License (http://creativecommons.org/licenses/by/4.0/), which permits unrestricted use, distribution, and reproduction in any medium, provided you give appropriate credit to the original author(s) and the source, provide a link to the Creative Commons license, and indicate if changes were made. The Creative Commons Public Domain Dedication waiver (http://creativecommons.org/publicdomain/zero/1.0/) applies to the data made available in this article, unless otherwise stated. we report a 12-year-old girl with anemia following a relative short-term zinc treatment for WD.

\section{Case presentation}

A 12-year-old girl was first noted to have elevated alanine aminotransferase (379 U/L, normal: $0-40 \mathrm{U} / \mathrm{L})$ and aspartate aminotransferase (218 U/L, normal, 0-40 U/L) when abdominal pain occurred at the age of 6 years. Viral serological markers (hepatotropic viruses, EpsteinBarr virus, and cytomegalovirus) were negative. Renal function tests, electrolyte and coagulation function were unremarkable. At the age of 7-year-old, her transaminase levels were still abnormal, and further investigations revealed low serum ceruloplasmin $(<0.079 \mathrm{~g} / \mathrm{L}$, cut-off value: $0.2 \mathrm{~g} / \mathrm{L}$ ) and increased 24-h urinary copper excretion $(360 \mu \mathrm{g}$, cut-off value: $40 \mu \mathrm{g})$ [18]. No corneal Kayser-Fleischer ring was observed by slit-lamp examination of her eyes. There was no family history of liver disease. Her parents and biological younger sister all had normal liver function tests. 
ATP7B (NM_ 000053) sequencing identified two novel heterozygous mutations, c.2122-1G $>\mathrm{T}$ (paternal) and c.3044 T > C, p. (L1015P) (maternal). Neither of these mutations have been described and recorded in the Exome Aggregation Consortium Server (http://www.exac. broad-institute.org) and the Thousand Genomes Project (http://www.1000genomes.org). They were predicted to be disease-causing by MutationTaster (http://www.mutationtaster.org). L1015P was also predicted to be probably damaging with a score of 1.000 by PolyPhen 2 (http://genetics.bwh.harvard.edu/pph2/index.shtml), and was predicted to affect protein function with a score of 0.00 by SIFT (http://sift.jcvi.org/www/SIFT_seq_submit2.html). The patient was treated with a low-copper diet, and zinc gluconate $(150 \mathrm{mg}$ of elemental zinc daily in three divided doses, at least half an hour before meals, which was gradually increased to $240 \mathrm{mg} /$ day due to persistently elevated liver aminotransferases and 24-h urinary copper excretion). She complained of occasional abdominal pain during the first three months of zinc therapy. Liver function tests returned to normal after six months. She has continued to take zinc at a dose of $240 \mathrm{mg} /$ day, and avoids foods with high copper content. Since her age of 8 years, no further visits to physicians were made until the patient was 11 years and 4 months old, when she presented with a pale face and fatigue. Whole blood cell counts disclosed severe normocytic anemia and neutropenia. She attended a pediatric hematology clinic and underwent anemia-related tests with no remarkable findings including negative direct and indirect Coombs tests, normal glucose-6-phosphate dehydrogenase activity and serum ferritin level. Serum zinc level was $530 \mu \mathrm{g} / \mathrm{dL}$ (normal:75-150 $\mu \mathrm{g} / \mathrm{dL}$ ) and serum copper level was $127 \mu \mathrm{g} / \mathrm{L}$ (normal: 800-1290 $\mu \mathrm{g} / \mathrm{L}$ ). Bone marrow cytology showed myelodysplastic syndrome. She received transfusion of 2 units of erythrocyte suspension and continued oral zinc at her previous dose. There was no significant improvement in hematological parameters.

She returned to us 6 months later. Physical examinations revealed a pale face, mild hepatomegaly and abnormal gait, no splenomegaly, no ascites, no personality change, no paresthesias, no myasthenia, no hypertonia or hyperreflexia. Whole blood cell counts showed white blood cells (WBCs): $2.21 \times 10^{9} / \mathrm{L}$ (normal: $4-10 \times 10^{9} / \mathrm{L}$ ), neutrophils: $0.08 \times 10^{9} / \mathrm{L}$ (normal: $1.8-6.3 \times 10^{9} / \mathrm{L}$ ), red blood cells (RBCs): $1.37 \times 10^{9} / \mathrm{L}$ (normal: $3.5-5.5 \times 10^{9} /$ L), hemoglobin (HGB): $4.0 \mathrm{~g} / \mathrm{dL}$ (normal: $11-13 \mathrm{~g} / \mathrm{dL}$ ), mean corpuscular volume: $85 \mathrm{fL}$ (normal: $82-100 \mathrm{fL}$ ), platelet count (PLT): $191 \times 10^{9} / \mathrm{L}$ (normal: $100-300 \times$ $10^{9} / \mathrm{L}$ ), and reticular erythrocyte ratio: $2.21 \%$ (normal: 0.5-1.5\%). Liver function tests demonstrated normal aminotransferases. Ferritin level was $313 \mathrm{ng} / \mathrm{mL}$ (normal: $13-150 \mathrm{ng} / \mathrm{mL}$ ). 24-h urinary copper excretion was $30 \mu \mathrm{g}$. Serum copper level was low $(56.3 \mu \mathrm{g} / \mathrm{L}$, normal: $800-1290 \mu \mathrm{g} / \mathrm{L})$. Serum zinc level was high $(500 \mu \mathrm{g} / \mathrm{dL}$, normal:75-150 $\mu \mathrm{g} / \mathrm{dL})$. Free copper level and 24-h urinary zinc excretion were not able to be tested. Renal function tests and urine analysis were unremarkable. Abdominal ultrasound revealed normal liver, spleen and gallbladder. There were no abnormal changes on brain Magnetic Resonance Imaging (MRI).Due to abnormal gait, studies of spinal MRI and cerebrospinal fluid were recommended, but rejected by her parents. In view of her severe anemia, 1 unit of erythrocyte suspension was transfused. We suspected that the anemia was possibly caused by hypocupremia secondary to zinc overtreatment. When zinc was withdrawn for 1 week, her hemoglobin level rose to $6.7 \mathrm{~g} / \mathrm{dL}$. She was then discharged and a normal diet was resumed. Low-dose zinc was recommended, but the girl's parents refused the treatment though we told the possible flare of liver damage, even acute liver failure after the cessation of zinc treatment. The patient was regularly followed up with liver function tests, whole blood cell counts and indices of copper metabolism. At the age of 12 years and 2 months (4 months after discharge), her hemoglobin level normalized and normal gait was restored. The latest follow-up was in May 2018 (9 months after discharge), and her whole blood cell counts and liver function tests were all within the normal range. The patient's hematological parameters, liver function tests, indices of copper and zinc metabolism are shown in Table 1.

\section{Discussion and conclusions}

Our patient originally presented with elevated liver aminotransferases, low serum ceruloplasmin, and increased 24-h urinary copper excretion. In addition, gene sequencing showed c.2122-1G > T and c.3044 T > C (p. L1015P) compound heterozygous mutations in ATP7B; thus, the diagnosis of WD was established. She was treated with a low-copper diet and zinc gluconate. Although we advised only avoid a few kinds of copper-rich food (shellfish, nuts, chocolate, mushrooms, and organ meats) [19], the family followed a very strict dietary copper restriction according to some propagations from the internet. Zinc is known to remove excess copper by inducing enterocyte metallothionein, which preferentially binds copper, prevents its absorption and enhances its excretion [20,21]. The guidelines recommend $150 \mathrm{mg}$ elemental zinc per day $(75 \mathrm{mg} /$ day for children $<50 \mathrm{~kg}$ in body weight) administered in three divided doses, 30 min before meals $[3,22]$, but administration of zinc is usually individualized according to clinical manifestation, biochemical indexes and 24-h urinary copper excretion [10].For patients on zinc maintenance therapy, 24-h urinary copper excretion, an indicator of blood free copper [3], should be monitored regularly and maintained between 30 and $75 \mu$ g; Besides, serum zinc levels 
Table 1 Laboratory findings of the present patient

\begin{tabular}{|c|c|c|c|c|c|c|c|c|c|c|}
\hline & $\begin{array}{l}\text { WBC } \\
\left({ }^{*} 10^{9} / L\right)\end{array}$ & $\begin{array}{l}\text { Neutrophils } \\
\left({ }^{*} 10^{9} / \mathrm{L}\right)\end{array}$ & $\begin{array}{l}\text { RBC } \\
\left({ }^{*} 10^{9} / \mathrm{L}\right) \\
\end{array}$ & $\begin{array}{l}\mathrm{HGB} \\
(\mathrm{g} / \mathrm{dL})\end{array}$ & $\begin{array}{l}\text { PLT } \\
\left({ }^{*} 10^{9} / \mathrm{L}\right) \\
\end{array}$ & $\begin{array}{l}\mathrm{ALT} \\
(\mathrm{IU} / \mathrm{L})\end{array}$ & $\begin{array}{l}\text { AST } \\
(\mathrm{IU} / \mathrm{L})\end{array}$ & $\begin{array}{l}\text { Serum copper } \\
\text { (ug/L) }\end{array}$ & $\begin{array}{l}\text { Serum Zinc } \\
(\mathrm{ug} / \mathrm{dl})\end{array}$ & $\begin{array}{l}\text { 24-h urine } \\
\text { copper (ug) }\end{array}$ \\
\hline $7 y^{a}$ & 6.9 & 1.35 & 4.66 & 13.7 & 183 & 324 & 294 & NA & NA & 360 \\
\hline $7 y 1 m$ & 6.5 & 1.30 & 5.0 & 12.9 & 194 & 210 & 158 & NA & NA & NA \\
\hline $7 y 6 m$ & 5.1 & 1.18 & 5.1 & 13.4 & 185 & 36 & 26 & NA & NA & NA \\
\hline $8 y$ & 6.1 & 1.24 & 5.3 & 14.5 & 196 & 43 & 33 & NA & NA & NA \\
\hline $11 y 4 m^{b}$ & 2.1 & 0.09 & 1.6 & 4.7 & 159 & 31 & 21 & 127.3 & 530 & NA \\
\hline $11 \mathrm{y} 10 \mathrm{~m}^{\mathrm{c}}$ & 1.5 & 0.08 & 1.37 & 4.0 & 191 & 16 & 17 & 56.3 & 500 & 30 \\
\hline $11 \mathrm{y} 10 \mathrm{~m}^{\mathrm{d}}$ & 2.2 & 0.11 & 2.27 & 6.7 & 251 & 20 & 18 & NA & NA & NA \\
\hline $12 y 2 \mathrm{~m}$ & 4.54 & 2.27 & 5.28 & 11.7 & 225 & 13 & 22 & NA & NA & NA \\
\hline
\end{tabular}

* : multiply by. a: age at initiation of zinc therapy. b: age at onset of anemia. c: age at withdrawal of zinc. d: 1 week after zinc withdrawal. $y$ years, $m$ months, NA not assessed

and urinary excretion of zinc should be maintained above $125 \mu \mathrm{g} / \mathrm{dL}$ and $1.5-2 \mathrm{~g} / \mathrm{d}$ respectively [19].Our patient was treated with high dose of zinc due to significantly elevated liver aminotransferases and 24-h urinary copper excretion. Abuduxikuer $\mathrm{K}$ and Wang JS conducted a retrospective study with an average 1.54-year follow-up revealed that a high dose of elemental zinc in Chinese children with presymptomatic WD had the same efficacy as the conventional dose and it took less time to normalize the liver function tests, with no influence on complete blood count parameters in the short-term [23]. It took 6 months for liver aminotransferases to normalize. The patient continued to receive high-dose zinc and was lost to follow-up for 3.3 years. At the age of 11.3 years, she was found to have severe anemia by the local heamatologist, without hemolysis or hemorrhage. She received erythrocyte transfusion, no cessation of zinc, which did not improve hypocupremia and anemia obviously, as Rau AR reported that anemia following penicillamine in a WD patient did not respond to treatment with hematinics [13]. The mechanism needs further study. When returned to our hospital for a follow-up, the patient was found to have low 24-h urinary copper excretion $(30 \mu \mathrm{g})$ with low serum copper level $(56.3 \mu \mathrm{g} / \mathrm{L})$, and significantly elevated serum zinc level $(500 \mu \mathrm{g} / \mathrm{dL})$, suggesting hypocupremia due to highdose zinc supplementation. Unfortunately, urinary zinc excretion test was not available at our institution. After the withdrawal of zinc with resumption of normal diet, hemoglobin levels were increased significantly. Low-dose zinc therapy was proposed to the patient, but parents refused despite of possibilities of liver damage or acute liver failure. Scheinberg $\mathrm{IH}$ et al. reported that eight patients died of hepatic decompensation or fulminant hepatitis after the withdrawal of decoppering therapy [24]. Moreover, the patient had been fed a strict lowcopper diet all long which aggravated negative copper balance.

Eight WD patients with hypocupremia-associated anemia following zinc therapy have been reported in the literature
[10-17]. Seven patients were adults. The only child among them was a 16-year-old boy who had anemia after initial penicillamine therapy for 2 year and anemia worsened after switching to high dose zinc for 9 months [13]. Five patients received over-dose zinc, while three received conventional dose. The anemia was severer in patients receiving high dose zinc treatment. Four individuals were treated with zinc monotherapy, one was treated with zinc plus trientine, and the remaining 3 patients took high-dose zinc with or after initial penicillamine administration. Whole blood counts in all these patients returned to normal after the appropriate treatment (1 patient after copper supplement, 1 patient after zinc dose adjustment, 4 patients after zinc withdrawal, and 2 patients managed with zinc withdrawal in combination with copper supplementation). Our patient presented with anemia and neutropenia due to hypocupremia following high-dose zinc monotherapy for 4 years and 4 months, and her hematological parameters recovered after zinc withdrawal for 4 months. Some physicians may suggest switching to D-penicillamine or trientine, as de-coppering drug, both of them can also lead to hypocupremia-related anemia, as previously reported $[25,26]$.The details regarding zinc therapy and anemia in these 9 patients are listed in Table 2

There are multiple causes of hypocupremia, mainly including copper malabsorption induced by short bowel syndrome, gastrointestinal surgery, Menkes disease and excessive zinc exposure due to WD, acne, and zinccontaining dental fixatives [27]. The characteristics of hypocupremia-associated anemia in different etiologies are similar. It may present as significant neutropenia, all forms of anemia (normocytic, macrocytic or microcytic), or thrombocytopenia. Bone marrow biopsy shows vacuolated myeloid and erythroid precursors, myelocytic dysplasia syndrome (MDS) or ring sideroblasts [28]. The exact mechanism of hypocupremia-related anemia is unclear and may involve the followings: Copper is a cofactor in many enzymatic redox reactions and can stimulate the transformation of divalent iron to trivalent 


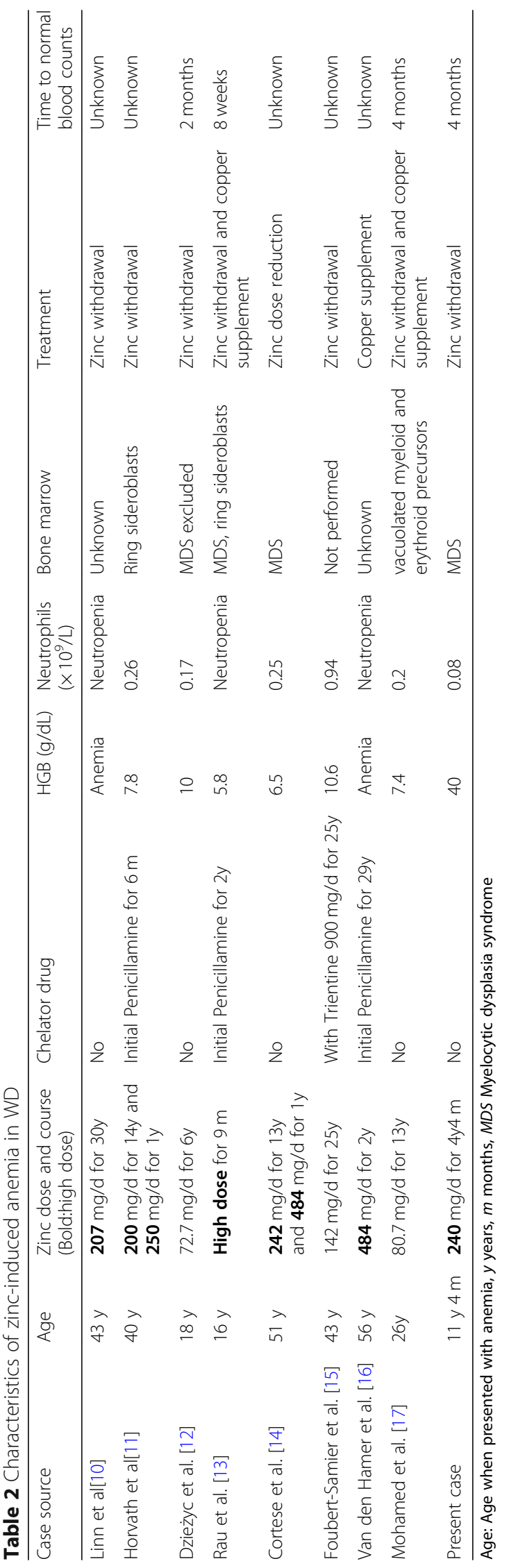


iron which participates in the hematopoietic process. Copper promotes release of iron from hepatocytes and iron absorption from enterocytes. Ceruloplasmin and transferrin are involved in iron transfer. Copper also accelerates the maturation and release of immature RBCs [29]. When copper is deficient, iron metabolism is disturbed, which affects the hematopoiesis process. Another copper dependent enzyme, cytochrome $\mathrm{C}$ oxidase, is also involved in the mechanism of anemia. Under low copper conditions, impaired cytochrome $\mathrm{C}$ oxidase affects the mobilization of stored iron, leading to iron deposition in tissues [30]. This may explain why the ferritin level was not low, different from iron-deficiency anemia. Because copper is a component of proteins which function in the structure and physiology of the central nervous system, hypocupremia can also cause demyelination of the central nervous system similar to vitamin B12 deficiency. Typical features include abnormal gait, paresthesias, myasthenia, hypertonia, or hyperreflexia. The MRI of brain is usually normal, while T2hyperintense signal can be seen in the dorsal columns of the spinal cord [31]. Our patient had a gait disorder, without other clinical symptoms of ataxia, myelopathy, and peripheral neuropathy. There were no abnormal changes on brain MRI. The reason for abnormal gait could not be ascertained because further studies of spinal cord MRI, and cerebrospinal fluid were refused by parents. Usually it may take longer time to develop copper deficiency in WD, but due to our patient's very strict diet control, higher zinc dose, and her relative low body weight, it took a shorter time to remove the excess copper accumulation in her body. The patient had not been back to us for years which prevented our clinicians identifying possible adverse effects promptly. Her hypocupremiaassociated anemia was not diagnosed until she returned to our liver specialist.

In conclusion, we report the first child patient with hypocupremia-associated anemia which developed following high-dose zinc monotherapy for Wilson's disease. Anemia during zinc therapy should prompt clinicians to exclude zinc over-treatment. Furthermore, this case demonstrates the importance of regular follow-up of whole blood cell counts, indices of copper and zinc metabolism, in the long-term management of WD [32], especially in whom high-dose zinc is administrated.

\section{Abbreviations \\ HGB: Hemoglobin; MDS: Myelocytic dysplasia syndrome; MRI: Magnetic Resonance Imaging; PLT: Platelet count; RBC: Red blood cell; WBC: White blood cell; WD: Wilson's Disease}

\section{Acknowledgments}

SC was supported by HM LUI Pediatric Liver Disease Fellowship Program.

\section{Authors' contributions}

SC drafted the manuscript; SC and JY performed the acquisition of clinical data; JYG and JSW contributed to patient management. JYG and JSW contributed to the design and supervised the manuscript preparation; SC, JYG and JSW contributed to revision of the manuscript; All authors read and approved the final manuscript. SC and JYG contributed equally to this paper.

\section{Funding}

This research was supported by the National Natural Science Foundation of China (Grant No. 81570568).

Availability of data and materials

All data generated or analyzed during this study are included in this published article.

\section{Ethics approval and consent to participate}

This article is a retrospective study and does not contain any studies with human subjects performed by any of the authors. So, the ethical approval was not necessary and Jinshan Hospital of Fudan University ethics committee can offer exempt ethical statement in support. Informed consent was obtained from the child's parents.

\section{Consent for publication}

Written informed consent for publication of clinical details was obtained from the guardians of the patient.

\section{Competing interests}

The authors declare that they have no competing interests.

Received: 12 December 2018 Accepted: 24 June 2019

Published online: 09 July 2019

\section{References}

1. Walshe JM. History of Wilson's disease:1912 to 2000. Mov Disorder. 2006;21: 142-7.

2. Bearn AG. A genetical analysis of thirty families with Wilson's disease (hepatolenticular degeneration). Ann Hum Genet. 1960;24:33-43.

3. Roberts EA, Schilsky ML. Diagnosis and treatment of Wilson disease:an update. Hepatology. 2008;47(6):2089-111.

4. Ala A, Walker AP, Ashkan K, Dooley JS, Schilsky ML. Wilson's disease. Lancet. 2007;369(9559):397-408

5. Lorincz MT. Neurologic Wilson's disease. Ann N Y Acad Sci. 2010;1184:173-87.

6. Wilson SAK. Progressive lenticular degeneration:a familial nervous disease associated with cirrhosis of the liver. Brain. 1912;34:295-507.

7. Wiernicka A, Jańczyk W, Dądalski M, Avsar Y, Schmidt H, Socha P. Gastrointestinal side effects in children with Wilson's disease treated with zinc sulphate. World J Gastroenterol. 2013;19(27):4356-62.

8. Lang CJ, Rabas-Kolominsky P, Engelhardt A, Kobras G, Konig HJ. Fatal deterioration of Wilson's disease after institution of oral zinc therapy. Arch Neurol. 1993;50:1007-8.

9. Walshe JM, Munro NA. Zinc-induced deterioration in Wilson's disease aborted by treatment with penicillamine, dimercaprol, and a novel zero copper diet. Arch Neurol. 1995;52:10-1.

10. Linn FH, Houwen RH, van Hattum J, van der Kleij S, van Erpecum KJ. Longterm exclusive zinc monotherapy in symptomatic Wilson disease: experience in 17 patients. Hepatology. 2009;50(5):1442-52.

11. Horvath J, Beris P, Giostra E, Martin PY, Burkhard PR. Zinc-induced copper deficiency in Wilson disease. J Neurol Neurosurg Psychiatry. 2010;81(12): 1410-1.

12. Dzieżyc K, Litwin T, Sobańska A, Członkowska A. Symptomatic copper deficiency in three Wilson's disease patients treated with zinc sulphate. Neurol Neurochir Pol. 2014;48(3):214-8.

13. Rau AR, Usha M, Mallya P, Rau AT. Cytopenia and bone marrow dysplasia in a case of Wilson's disease. Indian J Hematol Blood Transfus. 2014;30(Suppl1): 433-6.

14. Cortese A, Zangaglia R, Lozza A, Piccolo G, Pacchetti C. Copper deficiency in Wilson's disease: peripheral neuropathy and myelodysplastic syndrome complicating zinc treatment. Mov Disord. 2011;26(7):1361-2.

15. Foubert-Samier A, Kazadi A, Rouanet M, Vital A, Lagueny A, Tison F, Meissner W. Axonal sensory motor neuropathy in copper-deficient Wilson's disease. Muscle Nerve. 2009;40(2):294-6.

16. van den Hamer CJ, Hoogenraad TU. Copper deficiency in Wilson's disease. Lancet. 1989;2(8660):442. 
17. Mohamed M, Johnston A, Maclaine Cross A, Sharma A. Reversible pancytopenia caused by severe copper deficiency in a patient with Wilson disease. Med J Aust. 2018;209:1112.

18. Nicastro E, Ranucci G, Vajro P, Vegnente A, lorio R. Re-evaluation of the diagnostic criteria for Wilson disease in children with mild liver disease. Hepatology. 2010;52:1948-56.

19. Socha P, Janczyk W, Dhawan A, Baumann U, D'Antiga L, Tanner S, et al. Wilson's disease in children: a position paper by the hepatology committee of the European Society for Paediatric gastroenterology, hepatology and nutrition. J Pediatr Gastroenterol Nutr. 2018;66:334-44.

20. Chang H, Xu A, Chen Z, Zhang Y, Tian F, Li T. Long-term effects of a combination of D-penicillamine and zinc salts in the treatment of Wilson's disease in children. Exp Ther Med. 2013;5(4):1129-32.

21. Brewer GJ, Hill GM, Prasad AS, Cossack ZT, Rabbani P. Oral zinc therapy for Wilson's disease. Ann Intern Med. 1983:99:314-9.

22. European Association for Study of Liver. EASL clinical practice guidelines: Wilson's disease. J Hepatol. 2012;56(3):671-85.

23. Abuduxikuer K, Wang J-S. Zinc mono-therapy in pre-symptomatic Chinese children with Wilson disease: a single center, retrospective study. PLoS One. 2014;9(1):e86168.

24. Scheinberg $I H$, Jaffe ME, Sternlieb I. The use of trientine in preventing the effects of interrupting penicillamine therapy in Wilson's disease. N Engl J Med. 1987;317:209-13.

25. Gollan JL, Hussein S, Hoffbrand AV, Sherlock S. Red cell aplasia following prolonged D-penicillamine therapy. J Clin Pathol. 1976;29:135-9.

26. Harada M, Miyagawa K, Honma Y, Hiura M, Shibata M, Matsuhashi T, et al. Excess copper chelating therapy for Wilson disease induces anemia and liver dysfunction. Intern Med. 2011;50:1461-4.

27. Halfdanarson TR, Kumar N, Li CY, Phyliky RL, Hogan WJ. Hematological manifestations of copper deficiency:a retrospective review. Eur J Haematol. 2008;80:523-31.

28. Gabreyes AA, Abbasi HN, Forbes KP, McQuaker G, Duncan A, Morrison I. Hypocupremia associated cytopenia and myelopathy:a national retrospective review. Eur J Haematol. 2013;90(1):1-9.

29. Myint ZW, Oo TH, Thein KZ, Tun AM, Saeed H. Copper deficiency anemia: review article. Ann Hematol. 2018;97(9):1527-34.

30. Klevay LM. "Myelodysplasia," myeloneuropathy, and copper deficiency. Mayo Clin Proc. 2006:81(1):132 author reply 132

31. Allred JW, Aulino JM. Hypocupremia-associated myelopathy. J Comput Assist Tomogr. 2007;31:157-9.

32. Merle U, Schaefer M, Ferenci P, Stremmel W. Clinical presentation, diagnosis and long-term outcome of Wilson's disease:a cohort study. Gut. 2007;56(1): $115-20$.

\section{Publisher's Note}

Springer Nature remains neutral with regard to jurisdictional claims in published maps and institutional affiliations.

Ready to submit your research? Choose BMC and benefit from:

- fast, convenient online submission

- thorough peer review by experienced researchers in your field

- rapid publication on acceptance

- support for research data, including large and complex data types

- gold Open Access which fosters wider collaboration and increased citations

- maximum visibility for your research: over $100 \mathrm{M}$ website views per year

At $\mathrm{BMC}$, research is always in progress.

Learn more biomedcentral.com/submissions 